\title{
2020 Akan Berakhir, Wabah Pandemi Virus Corona Pula Belum Juga Mereda
}

\author{
Siti Zulfiah \\ IImu Al-Qur'an dan Tafsir, UIN SMH Banten \\ sitizulfiah1212@gmail.com
}

\begin{abstract}
Abstrack:
The pandemic or the Corona or Covid-19 virus outbreak began to appear in November last year and only appeared in Indonesia around last March. The Corona virus or Covid-19 is a deadly infectious disease, although it is not as dangerous as the viruses that hit the world in 2002, namely SARS and the MERS virus which first appeared in the Middle East in 2012. Although the viruses that cause these three diseases are actually come from the same virus family, but these three diseases have different incubation periods. The incubation period for MERS disease is 2-14 days (mean 5 days), and the incubation period for SARS disease is 1-14 days (mean 4-5 days). Meanwhile, the incubation period for COVID-19 is 114 days, with an average of 5 days. After the spread of this virus among the public at large, the government swiftly made a lot of regulations related to health protocols that were conveyed through various mass media and of course electronic media as well because as we know today more people use gadgets or cell phones to access. news rather than reading mass media such as newspapers or magazines.
\end{abstract}

Keywords: Disaster, Pandemic, Prevention

\section{Abstrak:}

Pandemi atau wabah virus Corona atau Covid-19 mulai muncul pada bulan November tahun lalu dan baru muncul di Indonesia sekitar bulan Maret yang lalu. Virus Corona atau Covid-19 ini adalah salah satu penyakit menular yang mematikan, meski tidak seberbahaya virus yang pernah menghantam dunia juga pada tahun 2002 yaitu SARS dan virus MERS yang pertama kali muncul di Timur Tengah pada tahun 2012. Meskipun virus penyebab ketiga penyakit ini sebenarnya berasal dari keluarga virus yang sama, namun ketiga penyakit ini memiliki masa inkubasi yang berbeda. Masa inkubasi penyakit MERS adalah 2-14 hari (rata-rata 5 hari), dan masa inkubasi penyakit SARS adalah 1-14 hari (rata-rata 4-5 hari). Sementara masa inkubasi COVID-19 adalah 1-14 hari, dengan rata-rata 5 hari. Setelah merebaknya virus ini di kalangan masyarakat banyak, pemerintah dengan sigap membuat banyak sekali peraturan terkait protokol kesehatan yang di sampaikan lewat berbagai media masa dan tentunya media elektronik juga karena seperti yang kita tahu saat ini orang-orang lebih banyak menggunakan gawai atau telepon seluler untuk mengakses berita daripada membaca media massa seperti koran atau majalah.

Kata Kunci: Bencana, Pandemi, Penanggulangan 


\section{Pendahuluan}

Siapa pun dapat terinfeksi virus corona. Akan tetapi, bayi dan anak kecil, serta orang dengan kekebalan tubuh yang lemah lebih rentan terhadap serangan virus ini. Selain itu, kondisi musim juga mungkin berpengaruh. Contohnya, di Amerika Serikat, infeksi virus corona lebih umum terjadi pada musim gugur dan musim dingin.

Di samping itu, seseorang yang tinggal atau berkunjung ke daerah atau negara yang rawan virus corona, juga berisiko terserang penyakit ini. Misalnya, berkunjung ke Tiongkok, khususnya kota Wuhan, yang pernah menjadi wabah COVID-19 yang bermulai pada Desember 2019.

Infeksi coronavirus disebabkan oleh virus corona itu sendiri. Kebanyakan virus corona menyebar seperti virus lain pada umumnya, seperti:

Percikan air liur pengidap (batuk dan bersin).

Menyentuh tangan atau wajah orang yang terinfeksi.

Menyentuh mata, hidung, atau mulut setelah memegang barang yang terkena percikan air liur pengidap virus corona.

Tinja atau feses (jarang terjadi)

Khusus untuk COVID-19, masa inkubasi belum diketahui secara pasti. Namun, rata-rata gejala yang timbul setelah 2-14 hari setelah virus pertama masuk ke dalam tubuh. Di samping itu, metode transmisi COVID-19 juga belum diketahui dengan pasti. Awalnya, virus corona jenis COVID-19 diduga bersumber dari hewan. Virus corona COVID-19 merupakan virus yang beredar pada beberapa hewan, termasuk unta, kucing, dan kelelawar.

Sebenarnya virus ini jarang sekali berevolusi dan menginfeksi manusia dan menyebar ke individu lainnya. Namun, kasus di Tiongkok kini menjadi bukti nyata kalau virus ini bisa menyebar dari hewan ke manusia. Bahkan, kini penularannya bisa dari manusia ke manusia.

\section{Pembahasan}

\section{Asal Mula Virus Corona}

Virus corona jenis baru yang tengah menyerang masyarakat dunia saat ini dalam istilah kedokteran disebut sebagai 2019 Novel Coronavirus (2019-nCoV). Dikutip dari Center for Disease Control and Prevention, cdc.gov, virus corona merupakan jenis virus yang diidentifikasi sebagai penyebab penyakit pada saluran pernapasan, yang pertama kali terdeteksi muncul di Kota Wuhan, Tiongkok. Virus Corona atau 2019-nCoV sudah memakan korban hingga ratusan orang meninggal dan puluhan ribu lainnya terinfeksi. Virus ini mudah sekali menyebar. Komisi Kesehatan Nasional China mengkonfirmasi virus corona dapat ditularkan dari manusia ke manusia yang terinfeksi. Bahkan virus itu bisa saja menempel di salah satu tempat dekat pasien corona. Virus ini pertama kali muncul di Wuhan, salah satu kota di China. Simpang siur kabar soal sumber kemunculan virus ini, mulai dari makanan hingga hewan-hewan unggas. Hal ini dikarenakan belum adanya informasi jelas soal asal muasal kemunculan virus tersebut. Virus ini diketahui pertama kali muncul di pasar hewan dan makanan laut di Kota Wuhan. Dilaporkan kemudian bahwa banyak pasien yang menderita virus ini dan ternyata terkait dengan pasar hewan dan 
makanan laut tersebut ${ }^{1}$ Orang pertama yang jatuh sakit akibat virus ini juga diketahui merupakan para pedagang di pasar itu. Satu hal yang paling mengkhawatirkan adalah virus ini terus mencari mangsa, sementara obatnya hingga saat ini belum ditemukan. Virus corona jenis baru mulai menjadi perhatian masyarakat dunia setelah pada 20 Januari 2020, otoritas kesehatan di Kota Wuhan, Provinsi Hubei, Tiongkok, mengatakan tiga orang tewas di Wuhan setelah menderita pneumonia yang disebabkan virus tersebut. Dikutip dari BBC, koresponden kesehatan dan sains BBC, Michelle Roberts and James Gallager mengatakan, di pasar grosir hewan dan makanan laut tersebut dijual hewan liar seperti ular, kelelawar, dan ayam. Mereka menduga virus corona baru ini hampir dapat dipastikan berasal dari ular. Diduga pula virus ini menyebar dari hewan ke manusia, dan kemudian dari manusia ke manusia².

Dinas Kesehatan (Dinkes) Jawa Tengah menyatakan, virus corona yang menular ke manusia bisa menyebabkan peradangan saluran pernapasan. Kepala Dinkes Jawa Tengah, Yulianto Prabowo mengungkapkan, dalam kondisi paling kritis seseorang yang terkena virus corona suhu tubuhnya bisa naik drastis lebih dari 38 derajat celcius.

"Gejalanya nyaris mirip flu biasa. Cuma demamnya lebih tinggi di atas 38 derajat. Kemudian penderitanya mengalami sakit kepala, batuk-batuk kering, kadang juga sesak napas. Tapi untuk infeksi paling berat bisa mengalami gagal napas," kata Yulianto kepada IDN Times, Senin (27/1).

la menuturkan jika tak dilakukan analisa yang cermat, petugas medis sulit membedakan antara flu dengan gejala virus corona. Secara umum, seorang yang terinfeksi virus corona memiliki gejala seperti demam, gangguan pernapasan, batuk pilek, sakit tenggorokan, dan letih.

Asal Mula Virus Corona Masuk ke Indonesia

Menelusuri jejak pasien yang terinfeksi Covid-19 sejak dini merupakan salah satu upaya untuk menekan penyebaran pandemi tersebut. Selain itu, identifikasi jenis atau tipe virus mematikan ini dapat membantu penelitian untuk penemuan vaksinnya. Langkah ini yang dilakukan oleh sejumlah negara, seperti Tiongkok dan Thailand. Bagaimana dengan Indonesia? Seorang pria berusia 55 tahun penduduk Kota Wuhan, Tiongkok tiba-tiba menderita demam tinggi berkepanjangan pada akhir Desember 2019. Tak diketahui penyakit yang dideritanya, tapi demam berlangsung hingga lebih dari dua pekan dengan disertai gangguan pernafasan. Pria yang juga pedagang di pasar hewan liar di ibu kota Provinsi Hubei itu kemudian diketahui terinfeksi virus corona, sekaligus disebut sebagai orang pertama yang menderita Covid-19. Belum jelas bagaimana dia bisa tertular virus tersebut. Dia diduga tertular dari hewan liar yang diperdagangkan di pasar tempatnya berjualan. Sejumlah peneliti kemudian menyimpulkan, virus baru ini masih satu keluarga dengan virus corona yang pernah mewabah, yakni SARS pada 2003 dan MERS pada 2012. WHO pun secara resmi menamakan virus baru ini sebagai Severe Acute Respiratory Syndrome Coronavirus (SARS-CoV-2) penyebab penyakit Covid-19. Selain pasien pertama, terdapat beberapa orang lagi di Wuhan yang mengalami gejala serupa. Virus yang diambil dari pasien-pasien tersebut kemudian diidentifikasi berdasarkan urutan molekul asam amino tunggal atau ribonucleic acid (RNA sequence). Hasilnya dapat dilihat dalam jurnal yang dipublikasikan bioRxiv. Dari 17 pasien yang dijadikan sampel, ternyata memiliki urutan RNA sama, dan lalu diberi nama subtipe O. Virus itu kemudian menyebar keluar Hubei, termasuk ke negara lain. Seperti Thailand yang pertama kali mendaftarkan

\footnotetext{
${ }^{1}$ Felliyanda Suci Agiesta, "Cerita Lengkap Asal Mula Munculnya Virus Corona di Wuhan", https://m.merdeka.com/dunia/cerita-lengkap-asal-mula-munculnya-virus-corona-di-wuhan.html, diakses pada tanggal 1 Desember 2020 pukul 14.38.

2 Denny Adhietya Febrian, Asal Mula dan Penyebaran Virus Corona dari Wuhan ke Seluruh Dunia, (https://bali.idntimes.com/health/medical/amp/denny-adhietya/asal-muasal-dan-perjalanan-virus-coronadari-wuhan-ke-seluruh-dunia-regional-bali), diakses pada tanggal 1 Desember 2020 pukul 16.12)
} 
virusnya ke GISAID pada 8 Januari 2020. Dalam artikel yang ditulis Chandrika Bhattacharyya et.al dari National Institute of Biomedical Genomics tersebut, virus subtipe $O$ bermutasi menjadi B dan B2 pada dua pekan pertama Januari 2020. Kemudian berevolusi lagi menjadi subtipe B1, B4, A2a, dan A3. Berdasarkan data Nextstrain.org yang didapatkan dari Global Initiative on Sharing All Influenza Data (GISAID), perbedaan tipe virus di luar Wuhan pertama kali ditemukan di Shenzen dan Guangdong. Di dua wilayah itu virus bermutasi menjadi tipe B2 pada 11 dan 15 Januari 2020. Sementara di luar Tiongkok, terdapat di Amerika Serikat (AS) dengan tipe B1 pada 19 Januari 2020. Virus di AS ini tercatat bertransmisi langsung dari Tiongkok ${ }^{3}$.

Ada lima penyebaran virus Corona dari manusia ke manusia, di antaranya:

1. Transmisi dari cairan: air dapat membawa virus dari pasien ke orang lain yang berada dalam jarak sekitar satu meter. Air yang dimaksud biasanya berupa cairan tubuh yang keluar saat berbicara, batuk, dan bersin.

2. Transmisi dari udara: virus corona bisa menyebar dalam jarak jauh melalui udara. Cara ini sama dengan cara virus flu, SARS, variola, dan norovirus menular dari satu orang ke orang lainnya.

3. Transmisi kontak: virus dapat menular melalui kontak langsung dengan kulit atau selaput lendir (seperti mata, lidah, luka terbuka, dan lain-lain). Transmisi juga bisa berlangsung melalui darah yang masuk ke tubuh atau mengenai selaput lendir.

4. Transmisi dari hewan: orang yang mengolah, menjual, dan mendistribusikan hewan liar yang membawa virus corona dapat tertular melalui kontak tersebut.

5. Kontak dekat dengan pasien: keluarga, orang yang tinggal serumah, petugas medis, atau bahkan orang yang sempat berada dekat dengan pasien rentan untuk tertular ${ }^{4}$.

\section{Cara Mengetahui Tertular Virus Corona}

Covid-19 telah menelan banyak korban jiwa. Sebagai upaya penanggulangan penyebaran, penting sekali bagi kita untuk mengenali gejala infeksi virus Corona, terutama gejala awalnya di minggu pertama.

Covid-19 merupakan infeksi virus yang menyerang sistem pernapasan manusia. Gejala yang disebabkan penyakit ini biasanya berawal dari gejala ringan. Setelah itu, gejala bisa membaik atau memberat, tergantung pada keadaan sistem imun tubuh penderita. Beberapa Gejala Infeksi Virus Corona di Minggu Pertama.

Gejala infeksi virus Corona bisa muncul dalam waktu 2-14 hari setelah terpapar virus Corona, tetapi kebanyakan penderita COVID-19 merasakan gejala setelah 11-12 hari.

Gejala yang terjadi di minggu pertama biasanya ringan. Berikut ini adalah gejala COVID-19 yang biasanya muncul di minggu pertama:

- Demam $\geq 38 h a r$

\footnotetext{
${ }^{3}$ Dwi Hadya Jayani, Asal Usul Virus Corona Masuk ke Indonesia, https://katadata.co.id/timdatajournalism/analisisdata/5ecb63ef78264/asal-usul-virus-corona-masuk-keindonesia, diakses pada tanggal 1 Desember 2020 pukul 22.40.

${ }^{4}$ Denny Adhietya Febrian, Asal Mula dan Penyebaran Virus Corona dari Wuhan ke Seluruh Dunia, https://bali.idntimes.com/health/medical/amp/denny-adhietya/asal-muasal-dan-perjalanan-virus-corona-dariwuhan-ke-seluruh-dunia-regional-bali, diakses pada tanggal 1 Desember 2020 pukul 16.12.
} 
- Kelelahan atau lemas

- Batuk tidak berdahak

- Pegal-pegal

- Tidak nafsu makan

- Hilangnya kemampuan mengecap rasa atau mencium

Karena sama-sama disebabkan oleh virus yang menyerang saluran pernapasan, gejala awal COVID-19 juga bisa mirip dengan flu biasa, yaitu pilek, hidung tersumbat, sakit kepala, dan sakit tenggorokan. Sesak napas bisa saja muncul di akhir minggu pertama, tetapi umumnya sesak napas mulai dirasakan mengganggu di minggu kedua.

Beberapa gejala awal lainnya yang mungkin dirasakan oleh penderita COVID-19 meliputi rasa tidak nyaman di perut, mual, dan diare, namun gejala ini tidak khas dan jarang terjadi.

Sesuai protokol kesehatan yang dikeluarkan oleh Kementrian Kesehatan Indonesia, ada 2 kriteria orang yang berisiko mengalami infeksi virus Corona, yaitu:

- Pernah kontak dengan pasien positif COVID-19, yaitu berada dalam satu ruangan yang sama atau berjarak 1 meter dengan penderita, dalam 14 hari terakhir

- Pernah berada di daerah endemis COVID-19, baik di dalam maupun di luar negeri, dalam 14 hari terakhir ${ }^{5}$.

Cara Penanggulangan Virus Corona

Seperti yang sudah kita ketahui, pemerintah sudah membuat peraturan mengenai cara pencegahan tertular Virus Corona. Banyak hal yang pemerintah anjurkan agar kita terhindar dari terpapar Virus Corona. Di antaranya:

- Memakai masker

- Menjaga jarak (Sosial Distancing)

- Menjaga kebersihan

- Cukup Minum Air

- Tidak bergerombol

- Mencuci tangan

1. Memakai Masker

Jika kamu sedang merasa tidak sehat, kamu dapat menggunakan masker untuk perlindungan mencegah penyakit corona. Kamu bisa menggunakan masker N95 atau masker bedah. Masker N95 lebih direkomendasikan sebab masker ini memiliki kemampuan proteksi yang sangat kuat.

Jika tidak terdapat masker N95, bisa menggunakan masker bedah. Namun pastikan penggunaannya benar, yakni masker tersebut harus menutupi mulut dan lubang hidung.

\footnotetext{
${ }^{5}$ Kenali Gejala Orang Terinfeksi Virus Corona di Minggu Pertama, https://www.alodokter.com/kenali-gejalaorang-terinfeksi-virus-corona-di-minggu-pertama, diakses pada tanggal 1 Desember 2020 pukul 23.02.
} 
Ketika masker itu sudah tidak layak digunakan, jangan ragu untuk membuangnya. Masker idealnya hanya dipakai dalam waktu sehari. Jika lebih dari itu dikhawatirkan masker ini akan menjadi tempat bakteri berkembang-biak ${ }^{6}$.

\section{Menjaga Jarak (Sosial Distancing)}

Satu di antara pencegahan penyebaran virus Corona yang efektif adalah jaga jarak sosial. Hal ini sebenarnya juga telah disuarakan oleh Pemerintah agar masyarakat jaga jarak fisik atau physical distancing. Dengan menerapkan physical distancing ketika beraktivitas di luar ruangan atau tempat umum, Anda sudah melakukan satu langkah mencegah terinfeksi virus Corona. Jaga jarak Anda dengan orang lain sekitar satu meter ${ }^{7}$.

\section{Menjaga Kebersihan}

Upayakan agar kebersihan rumah dan lingkungan selalu terjaga. Bersihkan kamar, lantai rumah, dan halaman rumah setiap hari. Ini cara mudah untuk menjaga lingkungan kita selalu dalam keadaan sehat.

4. Cukup Minum Air

Penuhi kebutuhan konsumsi air setiap hari. Langkah ini tepat untuk meningkatkan kesehatan tubuh. Setidaknya minum 8 gelas air atau sekitar 1.5 liter setiap hari agar kebutuhan cairan tubuh selalu tercukupi.

\section{Tidak Bergerombol}

Belum lama ini pemerintah menggencat aturan agar masyarakat tidak berkumpul dengan banyak orang atau tidak mengadakan acara yang mengundang banyak orang.

6. Mencuci Tangan

Rajinlah mencuci tangan menggunakan sabun atau dengan cairan pembersih berbasis alkohol (hand sanitizer). Mengapa cuci tangan penting untuk menangkal virus corona?

Karen Fleming, seorang profesor Biofisika dari John Hopkins University melalui akun Twitternya, dikutip Forbes, menjelaskan virus corona merupakan virus yang terbungkus oleh lapisan lemak. Air sabun atau hand sanitizer mampu untuk melarutkan lapisan lemak tersebut sekaligus membasmi virus corona.

Cuci tangan ini perlu dilakukan sebelum dan setelah makan. Di samping itu, hindari untuk sering menyentuh bagian mulut atau hidung dengan tangan. Sebab dikhawatirkan virus corona yang menempel di tangan kemudian akan menyebar lebih luas lewat mulut atau wajah.

\footnotetext{
${ }^{6}$ Aileen Velishya, 14 Cara Mencegah Virus Corona yang Efektif, https://jovee.id/14-cara-mencegah-viruscorona-yang-efektif/, diakses pada tanggal 1 Desember 23 pukul 23.34.

${ }^{7}$ Dandy Bayu Bramasta, Simak Ini 10 Cara Pencegahan Agar Terhindar dari Virus Corona, https://www.google.com/amp/s/amp.kompas.com/tren/read/2020/03/26/195000165/simak-ini-10-carapencegahan-agar-terhindar-dari-virus-corona, diakses pada tanggal 1 Desember 2020 pukul 23.41.
} 
Saat bepergian, kamu bisa membawa hand sanitizer. jika menyentuh permukaan yang sering disentuh orang, seperti tombol lift atau gagang pintu, kamu bisa gunakan hand sanitizer terlebih dulu ${ }^{8}$

\section{Hadist dan Dalil Tentang Wabah}

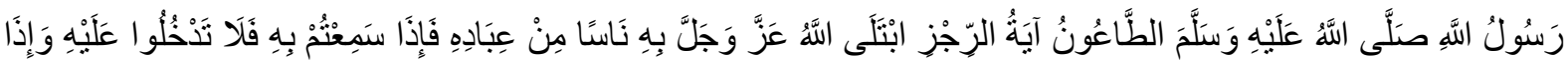

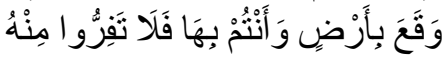

Rasulullah shallallahu 'alaihi wasallam bersabda: "Tha'un (wabah penyakit menular) adalah suatu peringatan dari Allah Subhanahu Wa Ta'ala untuk menguji hamba-hamba-Nya dari kalangan manusia. Maka apabila kamu mendengar penyakit itu berjangkit di suatu negeri, janganlah kamu masuk ke negeri itu. Dan apabila wabah itu berjangkit di negeri tempat kamu berada, jangan pula kamu lari daripadanya." (HR Bukhari dan Muslim dari Usamah bin Zaid).

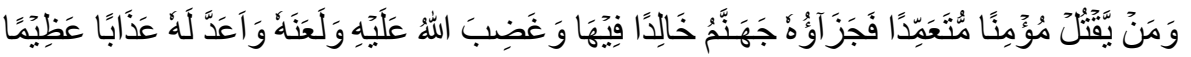

Dan barangsiapa membunuh seorang yang beriman dengan sengaja, maka balasannya ialah neraka Jahanam, dia kekal di dalamnya. Allah murka kepadanya, dan melaknatnya serta menyediakan azab yang besar baginya. (QS. An-Nisa:93) ${ }^{9}$.

\section{PENYELENGGARAN IBADAH DALAM SITUASI TERJADI WABAH COVID-19}

Ketentuan Hukum

1. Setiap orang wajib melakukan ikhtiar menjaga kesehatan dan menjauhi setiap hal yang diyakini dapat menyebabkannya terpapar penyakit, karena hal itu merupakan bagian dari menjaga tujuan pokok beragama (al-Dharuriyat al-Khams).

2. Orang yang telah terpapar virus Corona, wajib menjaga dan mengisolasi diri agar tidak terjadi penularan kepada orang lain. Baginya shalat Jumat dapat diganti dengan shalat zuhur di tempat kediaman, karena shalat jumat merupakan ibadah wajib yang melibatkan banyak orang sehingga berpeluang terjadinya penularan virus secara massal. Baginya haram melakukan aktifitas ibadah sunnah yang membuka peluang terjadinya penularan, seperti jamaah shalat lima waktu/ rawatib, shalat Tarawih dan led di masjid atau tempat umum lainnya, serta menghadiri pengajian umum dan tabligh akbar.

3. Orang yang sehat dan yang belum diketahui atau diyakini tidak terpapar COVID-19, harus memperhatikan hal-hal sebagai berikut:

\footnotetext{
${ }^{8}$ Aileen Velishya, 14 Cara Mencegah Virus Corona yang Efektif, https://jovee.id/14-cara-mencegah-viruscorona-yang-efektif/, diakses pada tanggal 1 Desember 23 pukul 23.53.

${ }^{9}$ http://m.muhammadiyah.or.id/id/news-18652-detail-hadis-yang-bisa-dijadikan-hujjah-dalam-menghadapiwabah-penyakit.html, diakses pada tanggal 1 Desember 2020 pukul 22.10.
} 
a. Dalam hal ia berada di suatu kawasan yang potensi penularannya tinggi atau sangat tinggi berdasarkan ketetapan pihak yang berwenang maka ia boleh meninggalkan salat Jumat dan menggantikannya dengan shalat zuhur di tempat kediaman, serta meninggalkan jamaah shalat lima waktu/rawatib, Tarawih, dan led di masjid atau tempat umum lainnya.

b. Dalam hal ia berada di suatu kawasan yang potensi penularannya rendah berdasarkan ketetapan pihak yang berwenang maka ia tetap wajib menjalankan kewajiban ibadah sebagaimana biasa dan wajib menjaga diri agar tidak terpapar virus Corona, seperti tidak kontak fisik langsung (bersalaman, berpelukan, cium tangan), membawa sajadah sendiri, dan sering membasuh tangan dengan sabun.

4. Dalam kondisi penyebaran COVID-19 tidak terkendali di suatu kawasan yang mengancam jiwa, umat Islam tidak boleh menyelenggarakan shalat jumat di kawasan tersebut, sampai keadaan menjadi normal kembali dan wajib menggantikannya dengan shalat zuhur di tempat masing-masing. Demikian juga tidak boleh menyelenggarakan aktifitas ibadah yang melibatkan orang banyak dan diyakini dapat menjadi media penyebaran COVID-19, seperti jamaah shalat lima waktu/ rawatib, shalat Tarawih dan led di masjid atau tempat umum lainnya, serta menghadiri pengajian umum dan majelis taklim.

5. Dalam kondisi penyebaran COVID-19 terkendali, umat Islam wajib menyelenggarakan shalat Jumat.

6. Pemerintah menjadikan fatwa ini sebagai pedoman dalam upaya penanggulangan COVID-19 terkait dengan masalah keagamaan dan umat Islam wajib mentaatinya.

7. Pengurusan jenazah (tajhiz janazah) terpapar COVID-19, terutama dalam memandikan dan mengkafani harus dilakukan sesuai protokol medis dan dilakukan oleh pihak yang berwenang, dengan tetap memperhatikan ketentuan syariat. Sedangkan untuk menshalatkan dan menguburkannya dilakukan sebagaimana biasa dengan tetap menjaga agar tidak terpapar COVID-19.

8. Umat Islam agar semakin mendekatkan diri kepada Allah dengan memperbanyak ibadah, taubat, istighfar, dzikir, membaca Qunut Nazilah di setiap shalat fardhu, memperbanyak shalawat, memperbanyak sedekah, dan senantiasa berdoa kepada Allah SWT agar diberikan perlindungan dan keselamatan dari musibah dan marabahaya (doa daf'u al-bala'), khususnya dari wabah COVID-19.

9. Tindakan yang menimbulkan kepanikan dan/atau menyebabkan kerugian publik, seperti memborong dan menimbun bahan kebutuhan pokok dan menimbun masker hukumnya haram. PENYELENGGARAN IBADAH DALAM SITUASI TERJADI WABAH COVID-1910

\footnotetext{
${ }^{10}$ Rayful Mudassir, Fatwa Lengkap MUI Terkait Pelaksanaan Ibadah saat Wabah Virus Corona Covid-19, https://m.bisnis.com/kabar24/read/20200319/15/1215355/fatwa-lengkap-mui-terkait-pelaksanaan-ibadahsaat-wabah-virus-corona-covid-19, diakses pada tanggal 1 Desember 2020 pukul 23.57.
} 


\section{Kesimpulan}

Dari tulisan di atas dapat kita simpulkan bahwa Virus Corona atau Covid-19 memang patut terus kita hindari hingga saat ini, walaupun sekarang mungkin media massa atau media elektronik tidak terlalu banyak lagi memberitakan mengenai hal ini tetapi bukan berarti bahwa pandemi ini sudah berakhir. Patut kita sadari bahwa begitu pentingnya mengikuti protokol kesehatan yang sudah diatur sedemikian rupa oleh pemerintah agar kita semua dapat terhindar dari paparan Virus Corona, mulai dari memakai masker, rajin mencuci tangan pakai sabun, menjaga jarak atau Physical Distancing, menjaga kesehatan dengan memperbanyak minum air putih atau bila perlu minum suplemen vitamin agar daya tahan tubuh tetap terjaga, rajin berolahraga tetapi tentunya tetap menerapkan Physical Distancing dengan tidak berkerumun. 


\section{Daftar Pustaka}

- Felliyanda Suci Agiesta, "Cerita Lengkap Asal Mula Munculnya Virus Corona di Wuhan", https://m.merdeka.com/dunia/cerita-lengkap-asal-mula-munculnya-virus-corona-di-wuhan.html, diakses pada tanggal 1 Desember 2020 pukul 14.38.

- Denny Adhietya Febrian, Asal Mula dan Penyebaran Virus Corona dari Wuhan ke Seluruh Dunia, https://bali.idntimes.com/health/medical/amp/denny-adhietya/asal-muasal-dan-perjalanan-virus-corona-dariwuhan-ke-seluruh-dunia-regional-bali, diakses pada tanggal 1 Desember 2020 pukul 16.12

- Dwi Hadya Jayani, 2020, Asal Usul Virus Corona Masuk ke Indonesia, https://katadata.co.id/timdatajournalism/analisisdata/5ecb63ef78264/asal-usul-virus-corona-masuk-ke-indonesia, diakses pada tanggal 1 Desember 2020 pukul 22.40.

- Kenali Gejala Orang Terinfeksi Virus Corona di Minggu Pertama, https://www.alodokter.com/kenali-gejala-orangterinfeksi-virus-corona-di-minggu-pertama, diakses pada tanggal 1 Desember 2020 pukul 23.02.

- $\quad$ Aileen Velishya, 2020, 14 Cara Mencegah Virus Corona yang Efektif, https://jovee.id/14-cara-mencegah-viruscorona-yang-efektif/, diakses pada tanggal 1 Desember 23 pukul 23.34.

- Dandy Bayu Bramasta, 2020, Simak Ini 10 Cara Pencegahan Agar Terhindar dari Virus Corona, https://www.google.com/amp/s/amp.kompas.com/tren/read/2020/03/26/195000165/simak-ini-10-carapencegahan-agar-terhindar-dari-virus-corona, diakses pada tanggal 1 Desember 2020 pukul 23.41.

- $\quad$ http://m.muhammadiyah.or.id/id/news-18652-detail-hadis-yang-bisa-dijadikan-hujjah-dalam-menghadapi-wabahpenyakit.html, diakses pada tanggal 1 Desember 2020 pukul 22.10.

- Rayful Mudassir, 2020, Fatwa Lengkap MUI Terkait Pelaksanaan Ibadah saat Wabah Virus Corona Covid-19, https://m.bisnis.com/kabar24/read/20200319/15/1215355/fatwa-lengkap-mui-terkaitpelaksanaan-ibadah-saat-wabah-virus-corona-covid-19, diakses pada tanggal 1 Desember 2020 pukul 23.57. 